\title{
Perceptions on the Internal Factors Influencing EFL Learning: A Case of Ecuadorian Children
}

\section{Paola Cabrera-Solano}

Universidad Técnica Particular de Loja, Ecuador, pacabrera@utpl.edu.ec

\section{Paul Gonzalez-Torres}

Universidad Técnica Particular de Loja, Ecuador,pfgonzalez@utpl.edu.ec

Lida Solano

Universidad Técnica Particular de Loja, Ecuador,Imsolano@utpl.edu.ec

\section{Luz Castillo-Cuesta}

Universidad Técnica Particular de Loja, Ecuador, lmcastillox@utpl.edu.ec

\section{José Jiménez}

The Canadian House Center, Ecuador, geovacan2@hotmail.com

\begin{abstract}
This study was conducted to identify teachers' and students' perceptions regarding the internal factors that influence English as a Foreign Language (EFL) learning in the southern region of Ecuador. The participants were 257 children, who answered a questionnaire about motivation, anxiety, willingness, self- efficacy and memorization when learning English skills. The English classes that these students took were observed during a three-month period. In addition, eight teachers were interviewed in order to know their views about the students' internal factors in EFL learning. After analyzing the data quantitatively and qualitatively, the results evidenced that, according to the participants' perceptions, motivation decreases depending on the students' age and the type of skills. Furthermore, anxiety when speaking in front of the class and doing listening activities increases as the students get older. Students are also self-efficient in the classroom, and they recall what they have learned. All the implications that can be derived from these factors should be carefully analyzed by educational stakeholders in order to help students succeed in the learning process.
\end{abstract}

Keywords: EFL learning, motivation, anxiety, self-efficacy, memorization

Citation: Cabrera-Solano, P., Gonzalez-Torres, P., Castillo-Cuesta, L., \& Jiménez, J. (2019). Perceptions on the Internal Factors Influencing EFL Learning: A Case of Ecuadorian Children. International Journal of Instruction, 12(4), 365-380. https://doi.org/10.29333/iji.2019.12424a 


\section{INTRODUCTION}

Teaching English as a Foreign Language (TEFL) is not an easy task because students may have different skills at different ages, and they do not develop them in the same way. EFL is an important component of the study plan in Ecuadorian elementary education. In fact, there are some common characteristics that can be pointed out when teaching English to children (Scott \& Ytreberg, 1990). One noteworthy feature of young children is that research demonstrates that they can learn a second language in the same way they acquire their first language, which means that they are natural language acquirers (Gordon, 2007). On the other hand, adults and adolescents go through a different learning process. However, an early age for learning another language is interrelated to other factors such as birth order; gender, personality, aptitude, and learning style, which affect children's language learning (King \& Mackey, 2007). Furthermore, some other factors are also essential in the success of learning a second language that can be categorized as internal (e.g. affective factors) and external or environmental factors (e.g. instruction) (Macaro, 2010). These factors will be addressed below.

External factors are related to the environment and curriculum in the context of language teaching (e.g. social class, teachers, L2 curriculum). Conversely, internal factors involve cognitive and emotional aspects such as motivation and anxiety (Mahmoudi \& Mahmoudi, 2015), willingness (Macaro, 2010), self-efficacy (Ersanl1, 2015), and memorization (Klemm, 2007).

Even though internal and external factors have been widely researched in the field of language teaching (e.g., Brown, 1995; Ellis, 2008; Nunan, 1988; Ortega, 2009), this research, conducted mainly in North America and Europe, has focused on separate factors. This means that little attention has been given to teachers' and students' perceptions regarding the influence of these factors on EFL learning, especially in the Ecuadorian context. In the case of the present study, we will focus on analyzing students and teachers' perceptions on internal factors such as motivation, anxiety, willingness, self- efficacy and memorization because they play a fundamental role in children's academic success or failure when learning English as a foreign language. Thus, the results obtained could be replicated in other similar Latin American contexts.

Based on the aforementioned aspects, the research questions to be addressed in this study are the following:

How do teachers and students perceive internal factors such as motivation, anxiety, willingness, self- efficacy and memorization in EFL learning?

- What are the implications that can be derived from the internal factors discussed in EFL teaching to children?

\section{REVIEW OF LITERATURE}

\section{Motivation and Willingness When Learning English}

Motivation is a factor that can affect language learning in people of all ages and involves willingness to reach a goal and positive attitudes towards learning (Gardner, 
1985). This factor is considered a learner-internal and affective factor that plays an important role in second language learning (Macaro, 2010). In the case of children, it has been associated with success in learning English (King \& Mackey, 2007). Furthermore, it works as an engine that supports the process of language acquisition. Without motivation, students will not be able to pursue an improvement in language proficiency, but if learners have a high motivation, they will have more probabilities to attain a proper proficiency in the L2 (Cheng \& Dörnyei, 2007).

It is necessary to mention that motivation can be intrinsic and extrinsic. Intrinsic motivation comes from within the individual, so students can be motivated by an enjoyable learning process or by an impulse to make themselves feel better when learning. On the other hand, extrinsic motivation comes from external factors (e.g. the need for passing a test or a reward); in other words, it comes from outside of the individual (Harmer, 2007).

\section{Learner's emotional factors when learning EFL}

According to López (2015), "emotions are context-dependent, short lived and subjective responses to a specific situation" (p.810). Pekrun (2014) argues that emotions are experienced by learners during lessons, while studying, and when taking tests and examinations. In addition, emotions are classified as positive or negative (e.g., Pekrun, Goetz, Titz \& Perry, 2002). Pekrun, Goetz, Frenzel, Barchfeld, and Perry (2011) claim that strong positive emotions allow students to get better academic success. On the contrary, negative emotions decrease motivation and attention, which leads to a reduction in academic performance (Lewis, Huebner, Malone \& Valois, 2011). Furthermore, Pekrun (2014) claims that these emotions can arise from life outside the classroom and many others are originated from academic settings.

With respect to academic settings, there are three aspects that can be considered. The first one is related to achievement emotions, which has to do with enjoyment of learning, hope and pride when success occurs, or anxiety and shame when failure happens at accomplishing achievement activities. Another aspect is epistemic emotions, which are very important when learning new, non-routine tasks; they are related to cognitive problems. For example, surprise about a new task, curiosity, confusion or frustration about obstacles. Topic emotions is another aspect and it belongs to the topics presented in lessons; positive or negative topic emotions can increase or decrease students' learning (Pekrun, 2014). Finally, social emotions, which have a special role in teacher/student interaction and group learning, deal with love, sympathy, compassion, admiration, contempt, envy, anger or social anxiety. From these social emotions, it can be seen that anxiety affects foreign language learning, so teachers should consider it to obtain better academic results (Chan \& Wu, 2004).

\section{Self-Efficacy for Developing School Activities}

According to Ersanlı (2015), self-efficacy consists of the belief of everyone's capacity to achieve, organize and perform a task effectively; in fact, Bandura (1977) mentions that academic success can be determined by individual's sense of self-efficacy. Caprara, Fida, Vecchione, Del Bove, Vecchio, Barbaranelli, and Bandura, (2008) go further 
when they argue that self-efficacy helps learners persist longer when facing difficulties and distractions. Linnenbrink and Pintrich (2003) claim that self-efficacy allows learners to be more cognitively, behaviorally and motivationally engaged in the learning process. In addition, Bandura (1995, p.203) explains that "self-efficacy involves judgements of capabilities to perform activities rather than personal qualities such as one's physical characteristics or psychological traits". This means that students can judge their capacity to fulfil a given activity, not how they feel about themselves as people. Hence, selfefficacy plays a substantial role on students' achievements with tasks, skills and knowledge.

\section{Memorization at Learning EFL}

Effective memorization is possible when a person can associate new and previous knowledge. Indeed, "a good memory expands the repertoire of cognitive capabilities upon which new understandings can be developed and expedited" (Klemm, 2007, p. 1). Memory is also an essential element for second language acquisition and communication (Bailer, Braga, \& Souza, 2013). Gathercole and Baddeley (2014) argue that memory plays an important role in language learning since it supports a whole range of complex everyday cognitive activities including language processing, reasoning and long-term learning. They also state that memory is involved in vocabulary acquisition, speech production, reading development, skilled reading and language comprehension

Regarding memorization in language learning, it can be considered as a means to consolidate new vocabulary and structures in the learner's brain (Liu, 2006). In addition, Mey (2009) asserts that memorization is a significant factor when learners need to learn nominal and verbal patterns and translate L1 into L2 or vice versa. In fact, memorization can help students improve English proficiency since they can recall and retain information about the language (Wood, 2010). In this regard, one way to improve retention rates in L2 learners is to use a collaborative knowledge sharing framework, which gives priority to the social interaction and active engagement of students to improve their English proficiency (Saeheaw, Sharp, Chakpitak, Meksamoot \& Adipattaranan, 2013). In cases such as L2 vocabulary learning, a good way to foster retention is through the use of vocabulary games (Liao \& Chen, 2012). On the other hand, teachers must be careful not to emphasize too much on recall and memorization because this approach may not promote critical and analytical skills in students (Sangnapaboworn, 2003).

\section{Previous Studies}

Several studies have been conducted about internal factors and their influence on second language acquisition. In this regard, we are going to show research conducted on internal factors such as motivation, anxiety, willingness, self- efficacy, and memorization because they play a significant role in children's academic success.

Memory is an important aspect in the acquisition of a second language. In this respect, Bailer, Braga, and Souza (2013) investigated the relationship between individual differences in working memory capacity (WMC) and learners' simultaneous attention to form and meaning in reading. The data were collected from 61 EFL Brazilian high 
school students by applying two working memory tests, three retrospective questionnaires, a task used to assess attention to form and meaning, and a feedback session. After the statistical analysis, the results revealed that attention to form and meaning in EFL reading is affected by individual differences in WMC because they were shown to determine efficient performance in the task of paying attention to form and meaning while reading.

Ersanl 1 (2015) carried out a study with the purpose of investigating the relationship between the academic self-efficacy levels and language learning motivation of 8th graders in Turkey. The descriptive method was used to examine the correlation between the academic self-efficacy levels and language learning motivation of students. The adapted version of 'Children's Perceived Academic Self-Efficacy Scale' by Jinks and Morgan (1999) was employed to collect data based on academic self-efficacy. The most important finding from this study shows that there is a significant difference in language learning motivation that favors girls. Regarding students' language learning motivation, it was found out that there is a significant difference between students whose parents graduated from universities (lowest level of self-efficacy) and students whose parents had primary and secondary school (higher level of self-efficacy).

Liu and Chen (2013) researched language anxiety in young EFL students and how it relates to two other major learner variables, multiple intelligences (MI) and learner attitudes. In their study, participants included 216 fifth and sixth graders from two elementary schools in central Taiwan. The findings indicate that the subjects experienced a fair amount of language anxiety. An analysis of student responses revealed that their top five concerns were: (1) failing English courses, (2) feeling that other students have a better English speaking ability, (3) feeling that other classmates have better English performance, (4) being called on in the English classroom, and (5) not being prepared in advance when the teacher asks questions. The results illustrate two major components of foreign language anxiety: general worry over language class performance and little confidence in speaking ability. Furthermore, language anxiety was found to be significantly and negatively related to all variables studied.

Vibulphol (2016) examined second language learners' motivation and learning of English and the ways in which teachers supported students' motivation and learning in natural classroom settings. This study was carried out in four main regions of Thailand. Observations and questionnaires to teachers and students were used as instruments; questionnaires were designed based on the Self-Determination Theory (SDT). The main participants of this study were ninth grade students and teachers, who were observed during twelve English lessons. Findings demonstrate that most students had a high level of motivation and many indicated that they have internal interests in learning English; nonetheless, the level of learning was not assessed to be as high as expected. Additionally, lack of motivation was shown in a few learners from almost every class. Teachers used a variety of motivational strategies such as autonomy-support and controlling styles. The results suggest the use of strategies that increase students' internal motivation in order to enhance sustainable learning of English in and outside the classroom. 


\section{METHOD}

\section{Sample}

This study was conducted in a partially-state subsidized school in southern Ecuador. The participants were 8 English teachers and 257 EFL students (63\% male and 37\% female) from eight classes who were purposefully selected. These students were enrolled in the first year ( 32 in class A and 33 in class $B=65$ ), second year ( 31 in class A and 33 in class $B=64)$, third year $(30$ in class $A$ and 31 in class $B=61$ ), and fourth year (33 in class $A$ and 34 in class $B=67$ ) of elementary education. They received two hours of English instruction per week during 4 months. Their ages ranged between 5 and 9 years (in the first year, 5 - 6 years old; second year, 6 - 7 years old; third year, 7 - 8 years old; fourth year, 8 - 9 years old).

The students' proficiency level, according to the Ecuadorian Ministry of Education, is pre-A1 of the Common European Framework of Reference for Languages (CEFR) (Council of Europe, 2001), which is divided into pre A1.1 (students in the first and second year of elementary education) and pre A1.2 (students in the third and fourth year of elementary education).

\section{Instruments and Materials}

A questionnaire about students' motivation, anxiety, willingness, self- efficacy and memorization when learning English skills was administered to students from first to fourth year of elementary education. This questionnaire was piloted and validated with a group of 30 students who had a similar age to the target group (10 per each year of elementary education, except for the first year), obtaining a Cronbach's alpha value of 0.847. In addition, a structured interview was applied to eight English teachers in order to identify their perceptions on the internal factors that influence EFL learning; and observation checklists were also used to obtain further information from the classes imparted.

Regarding the students' questionnaire, it consisted of 5 sections (one per internal factor) that contained 5 multiple choice items. The questions were written in Spanish using simple terms so the students can easily understand them. The teachers' interview consisted of 6 open-ended questions about the aforementioned internal factors. Furthermore, the observation checklists contained 5 sections with 3 items each in which the researchers had to register the aspects related to students' attitudes in the classroom.

\section{Procedure}

The participants (257 EFL learners) were asked to complete a questionnaire. In the case of students from the first year (5 to 6 years old), it was necessary to read the questions in Spanish so they can understand them. Afterwards, the researchers helped learners fill in the questionnaires. This procedure was done because of the students' early age. Additionally, teachers were interviewed to gather information about the internal factors that affect their EFL learners. The responses gathered were recorded in audio format; later, the most important opinions were transcribed, categorized and analyzed. 
Furthermore, four researchers were in charge of observing eight English classes (2 classes each) in order to verify the real situation of students in the classroom.

In order to analyze, describe and interpret the information gathered from the instruments, qualitative and quantitative methods were chosen since they allowed the researchers to have a deeper understanding of the research problem because, in the case of the present study, only one approach would not be so effective. The information was processed and analyzed using SPSS software and Excel.

\section{FINDINGS}

In order to answer our first research question, we used the information from all of the instruments designed for this study. Regarding the second research question, the teachers' interview and the observations were very useful to come up with implications derived from the internal factors under study.

\section{Students' Questionnaire}

At the beginning of the study, students were asked some background questions in order to know their perceptions about the English course. The results indicated that most of the students liked to learn this language (first year $86 \%$, second year $67 \%$, third year $82 \%$, and fourth year $85 \%$ ). Regarding their perceptions of the difficulty of the English course, table 1 shows that younger learners (first and second year) considered it as easy. On the other hand, older students (third and fourth year) found it more difficult to learn.

Table 1

Students` Difficulty to Learn English

\begin{tabular}{llll}
\hline Academic years & Age & Easy & Difficult \\
\hline First year & $5-6$ & $93 \%$ & $7 \%$ \\
Second year & $6-7$ & $90 \%$ & $10 \%$ \\
Third year & $7-8$ & $44 \%$ & $56 \%$ \\
Fourth year & $8-9$ & $56 \%$ & $44 \%$ \\
\hline
\end{tabular}

Regarding students' motivation to learn listening, speaking, reading and writing, most of the participants feel motivated to learn these skills. Figure 1 shows that students from the first year were highly motivated to learn listening and speaking. In the second year, it is evident that motivation decreases in comparison to the other levels. In the third and fourth year, students' motivation for learning listening and speaking skills is lower in comparison to reading and writing skills. 


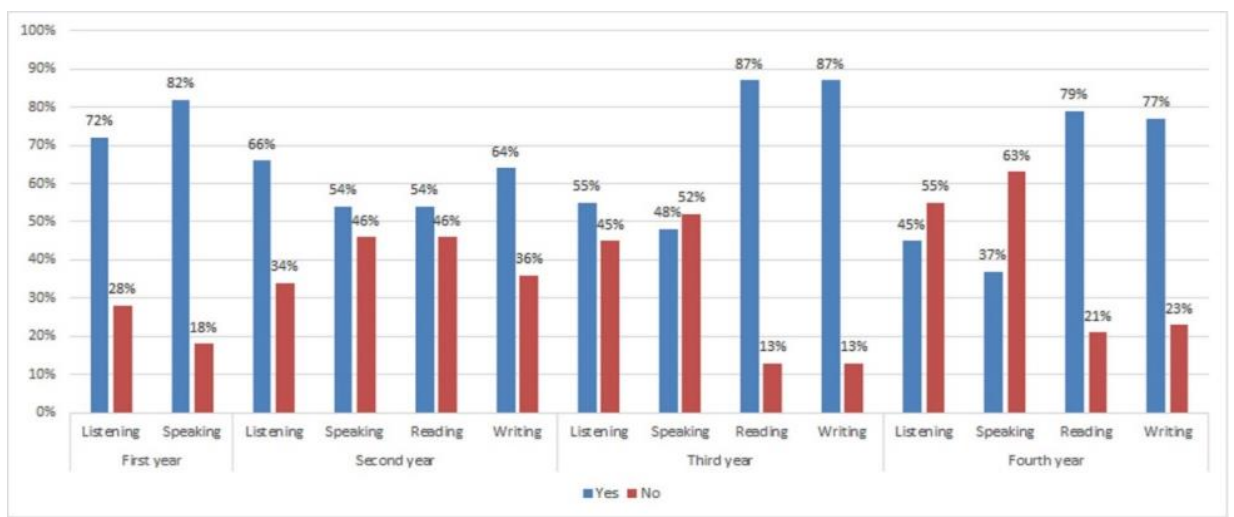

Figure 1

Students' Motivation to Learn Language Skills

Figure 2 below indicates the results concerning anxiety to learn language skills. Students in the first year were only asked about listening and speaking because their age did not allow them to perform a significant amount of reading and writing activities. In this case, these students showed a very low level of anxiety in the previously mentioned skills. Students from the second year also presented a low level of anxiety, except for reading skills in which the percentages were almost similar between students who felt comfortable when practicing this skill and those who did not. The level of anxiety when learning reading and writing skills was very low in the students from the third year; however, there were similar percentages regarding the students who felt anxious and those who felt comfortable when performing listening and speaking activities. The results from the fourth year took an interesting turn because the level of anxiety increased when learners attempted to acquire listening and speaking skills. On the other hand, these students showed lower levels of anxiety in reading and writing skills.

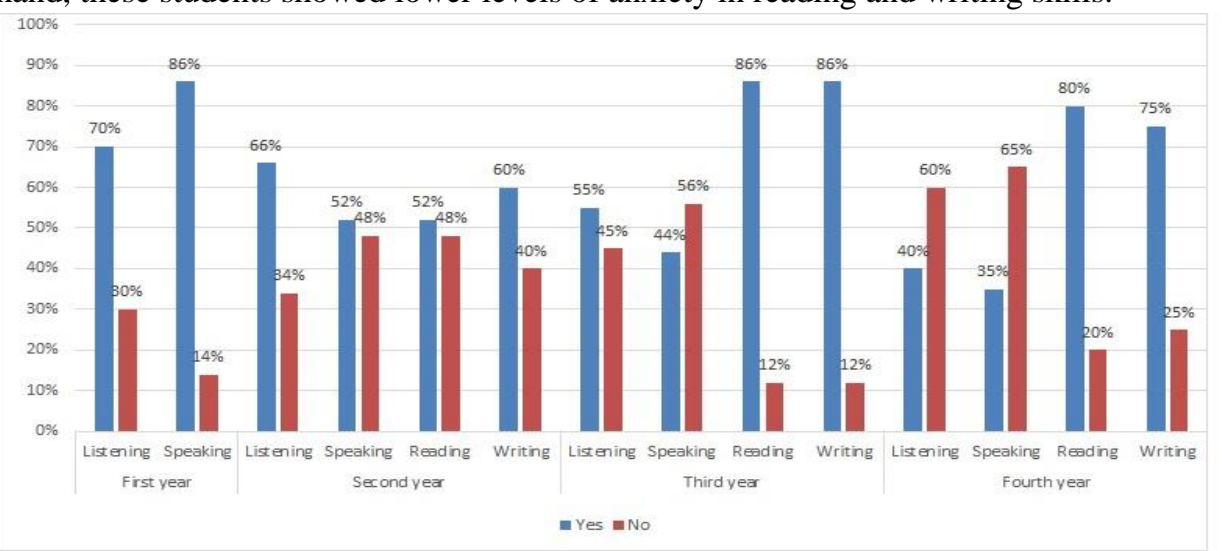

Figure 2

Students' Anxiety to Learn Language Skills 
Another aspect that was considered in this research was students' willingness to learn English (figure 3). In this respect, students from the first, second, third and fourth year expressed their desire to learn all language skills since the majority of them perceived that English activities are easy to develop and pertinent to their academic level.

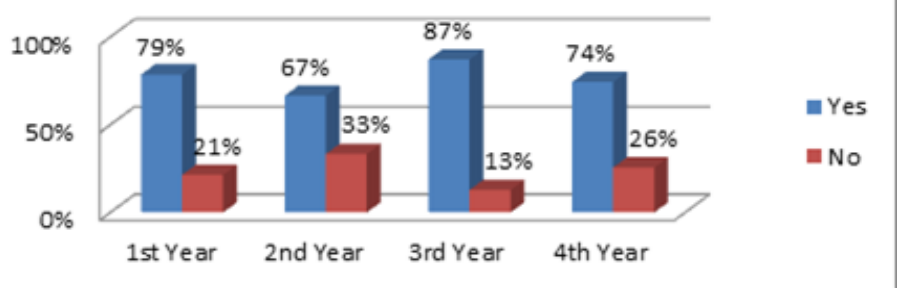

Figure 3

Students' Willingness to Learn English

Regarding self-efficacy, when performing classroom activities to practice all language skills, first year students (89\%) were self-sufficient, according to their own perception. In the same way, a high percentage of students in the second, third and fourth years indicated that they perform activities in an easy and effective way (figure 4).

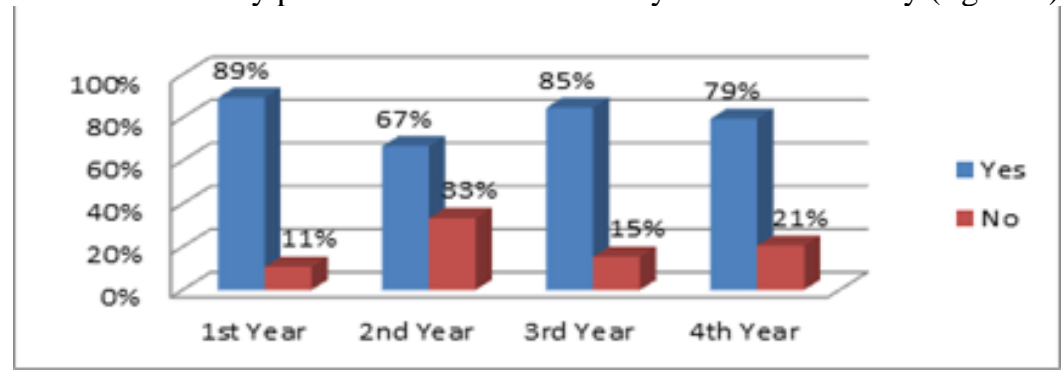

Figure 4

Students' Self-Efficacy When Doing English Activities in the Classroom

Figure 5 shows students' perceptions about memorization. According to the results, the majority of students from the first to fourth year can remember what they learn in English; they recall aspects such as vocabulary and grammar structures, as it was observed in the lessons. On the other hand, a few students do not easily remember what they have learned in the previous classes and affirm that although they like English, it is difficult for them to memorize all of the new information. 


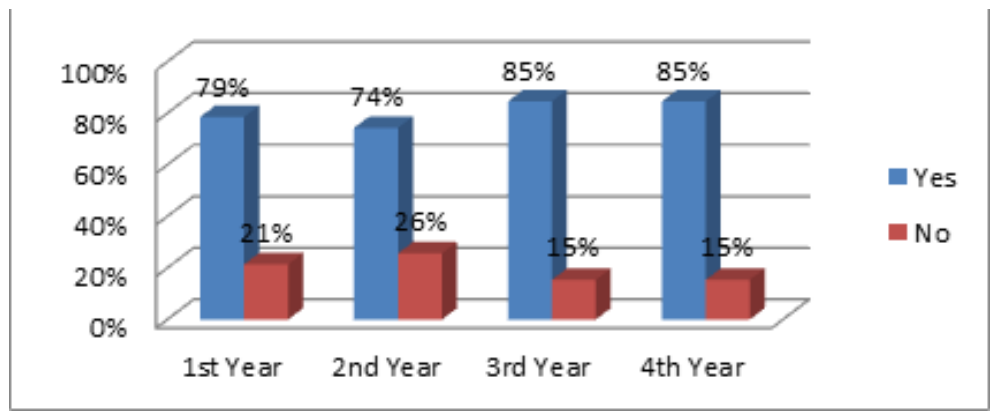

Figure 5

Students' Memorization

\section{Teachers' Interview and Observation}

Table 2 collects teachers' opinions about internal factors that influence EFL learning. The interview included questions related to what activities were motivating for students, whether it is difficult to motivate students in the classroom, the situations that could cause anxiety in the class, learners' willingness to participate in class activities, whether learners overcome challenges in the learning process, and how students memorize what they learn.

The responses obtained were similar in most of the cases, pointing out to a positive perception of learners' motivation, willingness, self-efficacy, and memorization. It was evident that the observation corroborated the results of the teachers' interview; for instance, in most of the lessons observed, students demonstrated openness and enthusiasm to be involved in the learning process. In fact, learners were eager to participate in all the activities that were planned by the teacher; they demonstrated that they felt capable and successful when fulfilling activities in the classroom. An aspect in which the observations partially differed from the teachers' opinions was the fact that some students were not able to recall the words they had previously learned in the oral or written activities.

Table 2

Answers to Teachers' Interview

\begin{tabular}{ll}
\hline Factor & Opinions \\
\hline Motivation & $\begin{array}{l}\text { Activities such as songs and games make lessons more dynamic and have a } \\
\text { positive effect on younger students' motivation. }\end{array}$ \\
& $\begin{array}{l}\text { It is difficult to motivate students in large classes, especially with 6-7-year- } \\
\text { old children. }\end{array}$ \\
Anxiety & $\begin{array}{l}\text { Students are afraid to make mistakes in front of the class. This fear seems to } \\
\text { decrease in younger students. }\end{array}$ \\
Willingness & $\begin{array}{l}\text { Students are eager to participate in all of the activities proposed in the } \\
\text { classroom. }\end{array}$ \\
Self-efficacy & $\begin{array}{l}\text { Students are able to face challenges in the learning process. } \\
\text { Memorization } \\
\text { Students remember previous knowledge and connect it to the new language } \\
\text { patterns they learn. }\end{array}$ \\
\hline
\end{tabular}




\section{DISCUSSION}

Regarding students' motivation to learn the four language skills in the first year, reading and writing were not considered in the study because students were still learning these skills in their mother tongue. Students were highly motivated to learn listening and speaking because teachers used activities involving songs and games to make classes more dynamic. These findings are consistent with Chou's (2014) results, who found that the use of these resources has a positive effect on learning since they increase young learners' motivation in the EFL classroom.

In the second year, motivation decreased in comparison to the other levels because the methodology applied by the teacher was not very appealing to this group of children. Furthermore, teachers explained that it is difficult to motivate students in large classes, especially in the second year. In fact, teaching to large classes means a challenge for teachers since it could decrease students' motivation, engagement, and higher cognitive skills (Hornsby, Osman \& De Matos-Ala, 2013).

In the third and fourth year, students' motivation for learning listening and speaking skills was lower than the one for developing reading and writing. These results can be explained based on the teachers' views that the students were ashamed of speaking and making mistakes in front of their classmates and teachers. In this respect, Kim (2018) emphasizes that many EFL learners consider speaking as the most important skill; however, it is the one that most reflects their anxiety individually or publicly, which may involve a decrease in motivation.

Concerning anxiety to learn language skills, Nilsson (2019) acknowledges that some degree of language anxiety may be inherent in the process of foreign language learning. Despite this claim, students from the second and third year of our study, in general, did not look anxious during the learning process. According to the teachers' perceptions, students in the fourth year showed more anxiety when developing listening and speaking skills. The teachers' views seemed to indicate that, as learners get older, they tend to be more afraid to express themselves orally. On the other hand, these students showed lower levels of anxiety in reading and writing skills, which differs from similar studies about anxiety where younger learners feel more anxious in foreign language learning contexts (e.g. Arnaiz \& Guillén, 2012) or there is no difference in anxiety levels between younger and older learners (e.g. Jafarigohar \& Behrooznia, 2012).

As for students' willingness to learn English, most of them expressed their desire to learn all language skills because they believed that the activities in the classroom are easy to do. They demonstrated openness and enthusiasm to be involved in the learning process. Indeed, willingness is an essential aspect when learning skills in the target language (Lightbown \& Spada, 1999), and it can describe, explain, and predict language learners' communicative behavior in the second language (Öz, Demirezen,\& Pourfeiz, 2015)

With respect to self-efficacy when performing classroom activities to practice all language skills, most students consider that they are self-efficient and perform activities 
in an easy and effective way. In this concern, it has been demonstrated that academic achievement improves when students' self-efficacy levels increase during the academic activities (Bandura, 1997; Rosário, Mourão, Trigo, Suárez, Fernández, \& TueroHerrero, 2011; Ferla, Valcke \& Cai, 2009).

Finally, based on the findings, we can claim that it is easy for most of the students from first to fourth year to remember vocabulary and grammar structures. However, a few of them were not able to recall the words they had previously learned in the oral or written activities. In that case, the appropriate use of activities that foster memorization is necessary. Regarding this issue, the use of memorization strategies, regardless of the onset age of active learning, is a factor that directly influences EFL students' success in language acquisition (Shin et al, 2018). Indeed, Oanh and Hien (2006) assert that memorization is one of the learning methods that benefits EFL learners to acquire and use the English language, and it also helps them to internalize what they have learned in order to apply it in authentic communication.

\section{CONCLUSIONS AND IMPLICATIONS}

The findings indicate that students, in general, feel motivated and willing to learn English language skills. However, this motivation decreases depending on the students' age and the type of skills. While younger students felt more motivated for developing listening and speaking activities based on songs and games, older students showed higher levels of motivation for reading and writing activities. In this context, teachers should consider students' age when planning activities for these groups of students in order to create an appropriate learning classroom environment.

Anxiety is generally low in the students, especially in first and second year. In the third and fourth year, the levels of anxiety increase when trying to learn listening and speaking skills. Apparently, according to students' and teachers' perceptions, anxiety at the moment of speaking in front of the class and doing listening activities increases as the students get older. This fact should be taken into consideration by teachers who should design activities that help students reduce their anxiety (e.g. group work, pair work, games, and other interactive activities).

Students are self-efficient at doing classroom activities to practice all language skills, which means that they can perform tasks in an easy and effective way. Students are also ready to meet academic challenges in their EFL classes. Teachers should take advantage of this situation and propose more challenging activities.

Students generally recall what they have learned in the EFL classroom mainly because the activities proposed by the teachers contribute to link students' previous knowledge to the new language patterns and vocabulary that they are taught. Therefore, teachers should design activities that provide significant learning to their students in a way that this information can be retained in the long-term memory.

Because of the students' early age, it was difficult to collect information when applying the questionnaires because they were not familiar with concepts such as self-efficacy, motivation, willingness, anxiety and memorization, so we had to use simpler language 
and questions such as "Can you do things by yourself?, Do you remember what words you learned yesterday?, Are you afraid when making mistakes when speaking? Do you enjoy your English class?, What do you like the most about your English classes?, among other questions.

It is necessary to mention that since this was a study conducted in only one school in Ecuador, the results obtained may not be generalized in other contexts. Further research about the external factors influencing EFL in children should be conducted in order to determine what can be done in terms of the children's learning environment and help them improve their learning process.

\section{ACKNOWLEDGEMENTS}

The authors express their gratitude to Universidad Técnica Particular de Loja authorities for promoting and supporting research projects through the EFL Learning, Teaching and Technology Research Group.

\section{REFERENCES}

Arnaiz, P., \& Guillén, F. (2012). Foreign language anxiety in a Spanish university setting: Interpersonal differences. Revista de Psicodidáctica, 17(1), 5-26.

Bailer, C., Braga, L., \& Souza, R. (2013). Working memory capacity and attention to form and meaning in EFL reading. Letras de Hoje, 48(1), 139-147.

Bandura, A. (1977). Self-efficacy: Toward a unifying theory of behavioral change. Psychological Review, 84(2), 191-215. doi: http://dx.doi.org/10.1037/0033295X.84.2.191.

Bandura, A. (1995). Self-efficacy in changing societies. New York: Cambridge University Press.

Bandura, A. (1997). Self-efficacy: The exercise of control. New York: Macmilllan.

Brown, J. (1995). The elements of language curriculum. Boston, Massachusetts: Heinle \& Heinle Publishers.

Caprara, G., Fida, R., Vecchione, M., Del Bove, G., Vecchio, G., Barbaranelli, C., \& Bandura, A. (2008). Longitudinal analysis of the role of perceived self-efficacy for selfregulated learning in academic continuance and achievement. Journal of Educational Psychology, 100(3), 525-534. doi: 10.1037/0022-0663.100.3.52.

Chan, D., \& Wu, G. (2004). A study of foreign language anxiety of EFL elementary school students in Taipei County. Journal of National Taipei Teachers College, 17(2), 287-320.

Cheng, H., \& Dörnyei, Z. (2007). The use of motivational strategies in language instruction: The case of EFL teaching in Taiwan. International Journal of Innovation in Language Learning and Teaching, 1(1), 153-174. doi: https://doi.org/10.2167/illt048.0. 
Chou, M. (2014). Assessing English vocabulary and enhancing young English as a Foreign Language (EFL) learners' motivation through games, songs, and stories. Education 3-13, 42(3), 284-297. doi: https://doi.org/10.1080/03004279.2012.680899.

Council of Europe. (2001). Common European Framework of Reference for Languages: Learning, Teaching, Assessment. Strasbourg: Language Policy Division, Council of Europe.

Ellis, R. (2008). The study of second language acquisition. New York: Oxford University Press.

Ersanl1, C. (2015). The relationship between students' academic self-efficacy and language learning motivation: A study of 8th graders. Procedia-Social and Behavioral Sciences, 199, 472-478. doi: 10.1016/j.sbspro.2015.07.534.

Ferla, J., Valcke, M., \& Cai, Y. (2009). Academic self-efficacy and academic selfconcept: Reconsidering structural relationships. Learning and individual differences, 19(4), 499-505. doi: https://doi.org/10.1016/j.lindif.2009.05.004.

Gathercole, S., \& Baddeley, A. (2014). Working memory and language. Psychology Press.

Gardner, R. (1985). Social psychology and second language learning: The role of attitudes and motivation. London: Edward Arnold.

Gordon, T. (2007). Teaching young children a second language. Westport: Greenwood Publishing Group.

Harmer, J. (2007). How to teach English. Harlow: Pearson Education Limited.

Hornsby, D., Osman, R., \& De Matos-Ala, J. (2013). Large-class pedagogy: Interdisciplinary perspectives for quality higher education. African Sun Media.

Jafarigohar, M., \& Behrooznia, S. (2012). The effect of anxiety on reading comprehension among distance EFL learners. International Education Studies, 5(2), 159-174. doi:10.5539/ies.v5n2p159.

Jinks, J., \& Morgan, V. (1999). Children's perceived academic self-efficacy: An inventory scale. The Clearing House, 72(4), 224-230.

Kim, J. (2018). Ongoing speaking anxiety of Korean EFL learners: Case study of a TOEIC intensive program. The Journal of AsiaTEFL, 15(1), 17-31. doi: 10.18823/asiatefl.2018.15.1.2.17.

King, K., \& Mackey, A. (2007). The bilingual edge: Why, when, and how to teach your child a second language. New York, NY: Collins.

Klemm, W. (2007). What Good Is Learning if You Don't Remember It? Journal of Effective Teaching, 7(1), 61-73. Retrieved from https://files.eric.ed.gov/fulltext/EJ1055665.pdf. 
Lewis, A., Huebner, E., Malone, P., \& Valois, R. (2011). Life satisfaction and student engagement in adolescents. Journal Youth Adolescence, 40(3), 249-262. doi: 10.1007/s10964-010-9517-6.

Liao, H., \& Chen, M. (2012). Effects of vocabulary games on lexical growth and retention of low-motivated EFL learners in Taiwan. Asia-Pacific Education Researcher, 21(3), 564-575.

Lightbown, L., \& Spada, N. (1999). How languages are learned. Oxford: Oxford University Press.

Linnenbrink, E., \& Pintrich, P. (2003). The role of self-efficacy beliefs in student engagement and learning in the classroom. Reading \& Writing Quarterly, 19(2), 119137. doi: 10.1080/10573560308223.

Liu, H., \& Chen, T. (2013). Foreign language anxiety in young learners: How it relates to multiple intelligences, learner attitudes, and perceived competence. Journal of Language Teaching and Research, 4(5), 932-938.

Liu, W. (2006). Memorization and improvisation: A comparison of two strategies in the oral acquisition of English as a second language (Unpublished doctoral dissertation). Australian Catholic University, Australia. Retrieved from http://researchbank.acu.edu.au/theses/163.

López, M. (2015). Emotional experiences of Mexican language learners: A qualitative study of their effects on motivation. Revista Brasileira de Linguística Aplicada, 15(3), 809-837.

Macaro, E. (2010). Continuum companion to second language acquisition. London: Bloomsbury Publishing.

Mahmoudi, S., \& Mahmoudi, A. (2015). Internal and external factors affecting learning English as a foreign language. International Journal of Language and Linguistics, 3(5), 313-322. doi: 10.11648/j.ij11.20150305.16.

Mey, J. (2009). Concise encyclopedia of pragmatics. Oxford: Elsevier Science.

Nilsson, M. (2019). Foreign language anxiety: The case of young learners of English in Swedish primary classrooms. Apples: Journal of Applied Language Studies, 13(2), 121. doi:10.17011/apples/urn.201902191584.

Nunan, D. (1988). Syllabus design. New York: Oxford University Press.

Oanh, D., \& Hien, N. (2006). Memorization and EFL students' strategies at university level in Vietnam. TESL-EJ, 10(2), 1-21.

Ortega, L. (2009). Understanding second language acquisition. London: Hodder Education. 
Öz, H., Demirezen, M., \& Pourfeiz, J. (2015). Willingness to communicate of EFL learners in Turkish context. Learning and Individual Differences, 37, 269-275. doi: 10.1016/j.lindif.2014.12.009.

Pekrun, R., Goetz, T., Frenzel, A., Barchfeld, P., \& Perry, R. (2011). Measuring emotions in students' learning and performance: The achievement emotions questionnaire (AEQ). Contemporary Educational Psychology, 36(1), 36-48. doi: 10.1016/j.cedpsych.2010.10.002.

Pekrun, R., Goetz, T., Titz, W., \& Perry, R. (2002). Academic emotions in students' self-regulated learning and achievement: A program of quantitative and qualitative research. Educational Psychologist, 37(2), 91-105. doi: 10.1207/S15326985EP3702_4.

Pekrun, R. (2014). Emotions and learning. France: Gonnet Imprimeur.

Rosário, P., Mourão, R., Trigo, L., Suárez, N., Fernández, E., \& Tuero-Herrero, E. (2011). English as a foreign language (EFL) homework diaries: evaluating gains and constraints for self-regulated learning and achievement. Psicothema, 23(4), 681-687.

Saeheaw, T., Sharp, B., Chakpitak, N., Meksamoot, K., \& Adipattaranan, N. (2013). Developing a collaborative knowledge sharing framework to promote English learning retention. International Journal of Innovation and Learning, 14(2), 121-144. doi: 10.1504/IJIL.2013.055520.

Sangnapaboworn, W. (2003). Higher education reform in Thailand: Towards quality improvement and university autonomy. Paper presented at the 8th Shizuoka Asia-Pacific Forum on Approaches to Higher Education, Intellectual Creativity, Cultivation of Human Resources seen in Asian Countries, Shizuoka, Japan.

Scott, W., \& Ytreberg, L. (1990). Teaching English to children. London: Longman.

Shin, S., Song, H., Choi, H., Hwang, M., Lee, H., Lee, Y., Oh, R., \& Lee, H. (2018). Why we do and what we do: The experience of good English language learners. The Journal of AsiaTEFL, 15(1), 130-147. doi: 10.18823/asiatefl.2018.15.1.9.130.

Vibulphol, J. (2016). Students' motivation and learning and teachers' motivational strategies in English classrooms in Thailand. English Language Teaching, 9(4), 64-75. doi: 10.5539/elt.v9n4p64.

Wood, D. (2010). Perspectives on formulaic language: acquisition and communication. London: Bloomsbury Publishing. 